\title{
SOME PHYZIOLOGICAL AND BIOCHEMICAL PROPERTIES OF MICROALGAE IN VEGETABLE SOIL
}

\author{
N.Buyankhishig ${ }^{1}$, Ch.Zultsetseg ${ }^{1}$, B.Odgerel $^{2}$ \\ ${ }^{1}$ Laboratory of Microbial Synthesis, Institute of Biology, zulaa178@yahoo.com \\ ${ }^{2}$ Faculty of Biology, the National University of Mongolia
}

Chlorella is included in a group of an autotrophic protococci alga and is occurred in ponds, wells, moist soil and on the surface of trees. It is circular in shape, $1.5-10.5 \mu \mathrm{m}$ in size and is a unicellular alga (1).

Among them, some strains of Chlorella genus contain $45-50 \%$ protein, 20 $25 \%$ carbohydrate, $7-10 \%$ lipids, and biologically active substances such as several types of vitamins and essential amino acids, hence, other countries are widely utilizing them in food, forage, pharmaceutical and cosmetic purposes (1.7).

Other countries are searching for chances to isolate a microalgae strain from their natural resources which can synthesize biologically active substances, to determine their properties, to utilize them practically and to produce their biopreparations by biotechnological methods (1.2.7).

Therefore, we studied the physiological and biochemical properties of the cultures that were isolated from the soil of a greenhouse in order to detect a biologically active microalgae strain.

\section{Materials and methods}

Strains Chlorella sp-47, Chlorella sp-48, Chlorella sp-49, Ch.vulgaris-50, Ch.vulgaris-51, Ch.vulgaris-52 from the algae library were used in our study. These strains have been cultivated in a luminostate under suitable ammonium nitrogen condition (2) which is enriched with $1.2 \mathrm{gm} / \mathrm{l}$ bicarbonate. Their growth activities and their dry weights were determined by physiological (6) methods. Total protein, lipid and carbohydrate of their biomass were determined by common biochemical methods (6.8).

\section{Results and discussion}

The microalgae species, which have a characteristic of accumulating its biomass under shorter period and suitable condition to produce a bio-preparation 
by biotechnological methods, have been drawing an increasing attention (1.4). The Chlorella species are the most suitable algae in this study (1.7.9).

1. Therefore, the seven strains of Chlorella genus which have been isolated from vegetable soil were cultivated in solid and liquid media and they have been inoculated in the standard medium from suspensions of the same growth level. Their growth activities and their dry weights have been determined and their results are shown in table 1.

Table 1. Growth activities and dry weights of strains

\begin{tabular}{|l|c|c|c|c|c|c|c|}
\hline Strain № & 47 & 48 & 49 & 50 & 51 & 52 & 53 \\
\hline $\begin{array}{l}\text { Growth activity } \\
\text { (million/ml) }\end{array}$ & 3.46 & 4.5 & 2.4 & 5.7 & 4.7 & 14.1 & 16.2 \\
\hline $\begin{array}{l}\text { Dry weight } \\
\text { (mg/ml) }\end{array}$ & 0.20 & 0.29 & 0.24 & 0.34 & 0.25 & 0.24 & 0.20 \\
\hline
\end{tabular}

If we can see from the table that the growth activities of these strains are 2.4-16.4 million $/ \mathrm{ml}$ and their dry weights are $0.20-0.34 \mathrm{mg} / \mathrm{ml}$. As we compare the growth activities of these strains to their dry weights, their relationship has been linear. For instance, Chlorella sp- 47 strain had $2.5 \mathrm{million} / \mathrm{ml}$ cells and its dry weight was $0.20 \mathrm{mg} / \mathrm{ml}$, while Chlorella sp-53 strain had $16.0 \mathrm{million} / \mathrm{ml}$ cells, however, its dry weight was $0.20 \mathrm{mg} / \mathrm{ml}$. This is related to the Chlorella $s p-47$ strain which has larger cells than the Chlorella $s p-53$ strain which has smaller cells.

2. Some biochemical components of these strains' biomass that was cultivated in the suitable 04 medium, has been determined and the results are shown in graph 2.

Graph 2

Biochemical components of Chlorella strains' biomass in(\%)

$\square$ Protein (\%) $\square$ Carbohydrate(\%) $\square$ Lipid (\%)

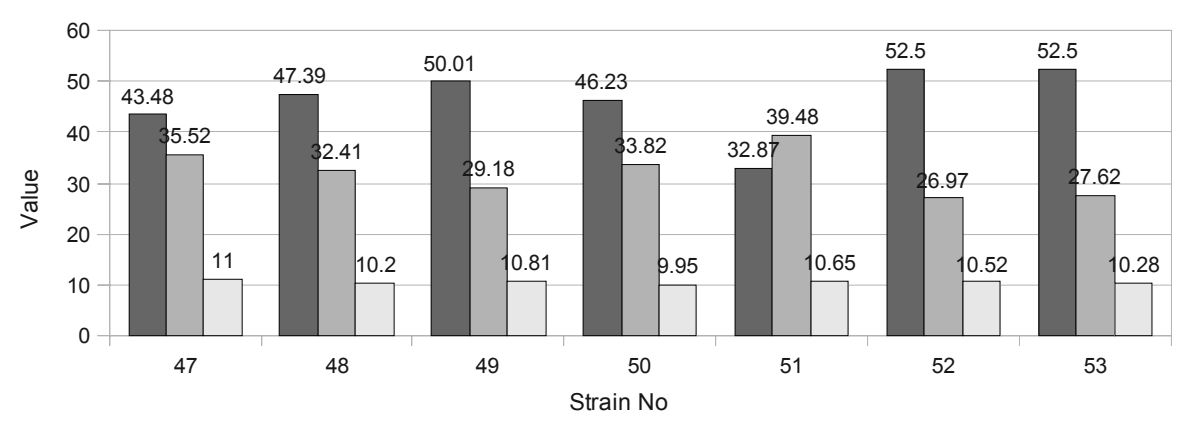

It is shown in graph 2 that the biomasses of the Chlorella strains have been cultivated in suitable medium, contained $32.87 \%-52.50 \%$ protein. The protein value was the highest in $50.01 \%-52.50 \%$ in the Chlorella sp- 53 , Ch.vulgaris- 52 and Chlorella sp-49 strains while it was decreased in Chlorella sp-48, Ch.vulgaris-50 
and Chlorella sp-47 strains and the lowest was $32.87 \%$ in Ch.vulgaris-51 strain.

The carbohydrate values of the Chlorella sp-48, Ch.vulgaris-50, Chlorellasp47 and Ch.vulgaris -51 strains reached $32.41 \%-39.48 \%$ while they were decreased to $29.18 \%-26.97 \%$ in Chlorella sp-49, Chlorella $s p-53$ and Ch.vulgaris52 strains.

The lipid values were $9.95 \%-11.0 \%$. Chlorella-sp 53 strain was predominating in its protein-carbohydrate synthesis in this study.

\section{Comparative values of Chlorella sp -53 strain's biomass \\ between other researchers' results}

Chlorella-sp 53 strain had close values of protein, carbohydrate, lipid and ashes to Chlorella sp (co-10), Chlorella ( $p-1)$ (Костина 1966) strains which could be seen in graph 3 .

\section{Conclusion}

Graph 3

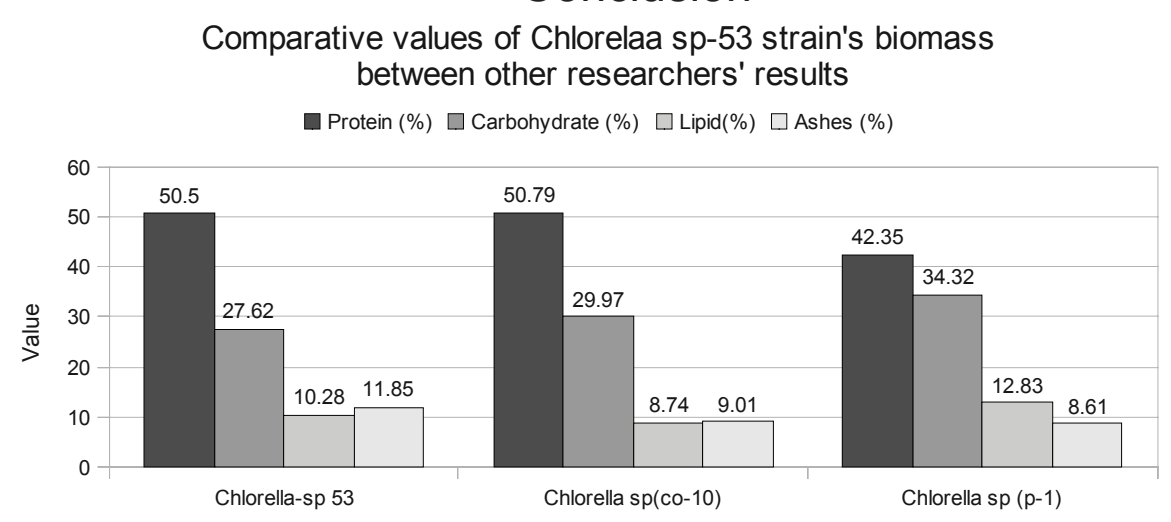

Protein, carbohydrate and lipid values have been found unequally in the biomasses of 7 unicellular algae strains of genus Chlorella. Among them, Chlorella-sp 53 strain gave the growth of $16.40 \mathrm{million} / \mathrm{ml}$ under suitable condition and its biomass contained $52.50 \%$ protein, $27.62 \%$ carbohydrate and $10.28 \%$ lipid. It had higher activity than in other strains hence this strain has been chosen in our further study. 


\section{References}

1. Андреева В.M. (1975) CHLORELLA.Морфология, систематика, принципы классификации.Л.,.110

2. Владимирова М.Г и др. (1962).Сравнительное изучение продуктивности различных фрорм одноклеточных водорослей. В сб.Проблемы космичекой биологии Т.2.М.. 314-320

3. Клячко-Гурвич Г.Л. (1966). К вопросу о направленном биосинтезе белков, углеводов и липидов у хлореллы. В кн:Управляемый биосинтезе.М..116-121

4. Курсанв Л.И Комерницкий А.Н (1947). Курс низших растении. М.,.3-10

5. Методы физиологи - биохимического исследования водорослей в гидробиологического практике. (1975). Киев.31-35. 101-105.

6. Музафраров А М и др (1984).Культивирование и применение микроводорослей Ташкент.3-9.78-82.

7. Бадгаа Д.Батмөнх нар. (1974).Ургамлын биохимийн шинжилгээний арга.УБ.С. 17-25. 75-82.

8. Богданов Н.И. (2007).Суспензия хлореллы в рационе сельскохозяйственных животных.Пенза,.6-11. 15-23. 